\title{
Scientific Discourse of Lakes in Nepal
}

\author{
D.R. Bhuju, S. Sharma ${ }^{1}$, P.K. Jha ${ }^{2}$ and N.P. Gaire \\ Nepal Academy of Science and Technology \\ Khumaltar, Lalitpur \\ ${ }^{1}$ Aquatic Ecology Centre, Kathmandu University \\ Dhulikhel, Kavre \\ ${ }^{2}$ Central Department of Botany \\ Tribhuvan University \\ Kirtipur, Kathmandu \\ e-mail:dineshbhuju@gmail.com
}

\begin{abstract}
Over 5,000 standing water bodies, including those $<1$ ha and spread in 74 districts of Nepal have been scanned on the topographic sheets (scale of 1:125,000). Majority of these lakes or ponds are either in the high altitudes (above $3,000 \mathrm{~m}$ ) or in lowland Tarai (below $500 \mathrm{~m}$ ). In a literature review we found over 163 research studies conducted since the first study of lakes in 1969 in Khumbu region, majority being at the initiative of national academia, their faculties and graduate students. However, a complete inventory of Nepal's lakes is still lacking. Their characteristics and distinction from wetlands are also to be defined as the existing laws and rules do not protect lakes or ponds categorically, rather they are blanketed under wetlands and/or other river like water resources. Research observations have shown that acid depositions are the most likely source of pollution affecting high altitude lakes in the Himalayan regions during spring. Their value as religious sites has also caused anthropogenic alteration in nutrient concentrations and biological assemblages of the lake. Encroachment to the lakes/ponds is rampant to which the natural processes of sedimentation, alien species invasion or any kind of obliteration become supportive. Capacity building, knowledge generation and threat management are vital to protect these natural heritages from untimely demise.
\end{abstract}

Key words: biodiversity, conservation, geographic coverage, socio-economic values, water bodies

\section{Introduction}

In Nepal, water bodies cover $5.06 \%$ of the total land area (FDD 1992). Of the estimated coverage of 720,000 ha of these water bodies, some $3.2 \%$ is occupied by lakes including ghole, ponds and reservoirs. The rest are river systems and paddy fields. Lakes and ponds play important role as wintering habitat and stoppage for a wide variety of migrant birds which cross the Himalaya on their way between breeding places in north and central Asia and wintering places further south in the Indian sub-continent (Scott 1989). In Nepal, about one fourth of its total biodiversity (estimated 6,500 vascular plants) is reported to be related to wetland and/or lakes (Bhandari 1992). The Nepali lakes are of natural as well as artificial, such as glacial and tectonic origin in the mountains or oxbow lakes in the lowlands, and man-dug near settlements.
Lakes hold multi-purpose values in Nepal and Nepali society. The majhis (fishermen) make livelihood out of the lake resources such as fish, while those dwelling in the lake vicinity directly use its water for drinking purposes and also for irrigating their agricultural lands. Every year, thousands of pilgrimage throng to high mountain lakes (e.g., Gosaikunda), and no less number of people celebrate Chhath dipping in the lakes in lowland Terai (e.g., Janakpur). Lakes play a vital role in national economic activities as they have been tourist destination (e.g., Pokhara). Many cities and settlements, where natural lakes do not exist, have maintained ponds; for example a small city Janakpur (area: 24.6 sq km) in Nepal Tarai has at least 45 ponds (Singh 2002). 
Bhuju et al. (2009) prepared a list of 5,358 lakes using the topographical sheets (total 706 sheets) encompassing Nepal's territory (area: 147,181 sq km). Of the 75 districts, 74 consisted lakes of varied size, from less than 1 ha to 800 ha (Rara Tal in Mugu). Four districts contained over 300 lakes in them, viz. Humla (381), Taplejung (380), Kapilbastu (351) and Solukhumbu (339). Altitudewise, over 2,700 (51.0\%) were found to be distributed below $500 \mathrm{~m}$, and 2,227 (42\%) above 3,000m. Only 419 (<8\%) were in the mid hills of altitudinal range between $500 \mathrm{~m}$ and 2,999m. The lowest altitude lake inventoried was in Dhanusha (unnamed, alt. 59m asl), and the highest altitude lake was in Mustang (Dhau Dhun Tal, alt. 5,905m asl). District Okhaldhunga is reported without a lake.

\section{Objective}

The objective of the present study was to understand the scientific discourse and priorities of various researches conducted on lakes and ponds of Nepal.

\section{Methodology}

We collected literature on studies of the lakes and ponds in Nepal conducted by various researchers, both through national and international efforts. The collected data span for four decades from 1960 to 2010. The studies were categorized by physiographic coverage denoting various ecological zones, their study scope and findings. The findings of the studies were analyzed by major priority areas such as biodiversity conservation, water quality analysis and pollution, cultural and management, etc. Based on the available information, we also listed some threats and suggestions.

\section{Findings and Analysis \\ Lake definition}

There is considerable uncertainty about definitions of lakes and distinction between lakes and ponds. Limnologists have defined lakes as water bodies that are simply larger versions of ponds, or that have wave action on the shoreline, or where wind-induced turbulence plays a major role in mixing the water column. In Nepal, a general terminology to denote lake in Nepali language is Tal (pronounced Taal, e.g., Phewa Tal) which generally refers to large water bodies of natural origin. Beside this, there are few other synonyms derived from Sanskrit such as Kunda (e.g., Gosainkunda), Jalasaya, Sarowar, Talau. A commonly used terminology is Pokhari, which generally means smaller water bodies of natural (e.g., Kanepokhari) as well as human made (e.g., Ranipokhari). The other terminologies to denote water bodies are Daha, Kuwa. Local communities use their own terminologies for lakes/ponds, examples, Pukhu (Newar), etc. Regardless of their definition and/or varied names, all kinds of water body have their role as habitat for myriad of organisms and do contribute in the ecosystem energetic.

\section{Publications}

Till 2010, 163 publications including masters' degree thesis on the study of lakes and ponds in Nepal were listed from various sources of information (Bhuju \& Gaire 2010). Besides these, 40 reports based on district level consultation and lake survey conducted by Nepal Academy of Science and Technology (NAST), National Trust for Nature Conservation (NTNC) and Central Department of Environmental Science, Tribhuvan University (CDES/TU) with support from National Lake Conservation Development Committee, Government of Nepal have been prepared. Of the total publications referred, 83\% were based on scientific objectives, mainly on water quality, fisheries and limnology (Fig. 1).

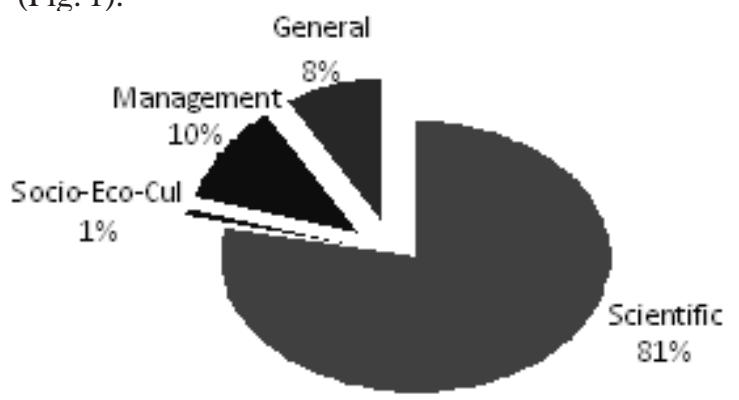

Fig. 1. Different aspects of research on lakes of Nepal

The first literature related to lakes of Nepal was the one by Löffler in 1969. He explored 24 high altitude lakes located at the altitude of 4,500 m-5,600 $\mathrm{m}$ asl in the Mount Everest region, and reported the first data on morphometry, temperature, chemistry and biology (Löffler 1969). During 1970s, the number of studies was eight, which increased to 20 during 1980s. During 1990s, the number of studies reached 58, particularly from Tribhuvan University. During 2001-2009, 76 studies on lakes and ponds had been conducted by various researchers (Fig. 2). Among scientific studies, 35 were Master degree theses in different disciplines of science mainly botany and environmental science. Ten percent of the studies had their management 
objectives. One study was also on general socio cultural aspects.

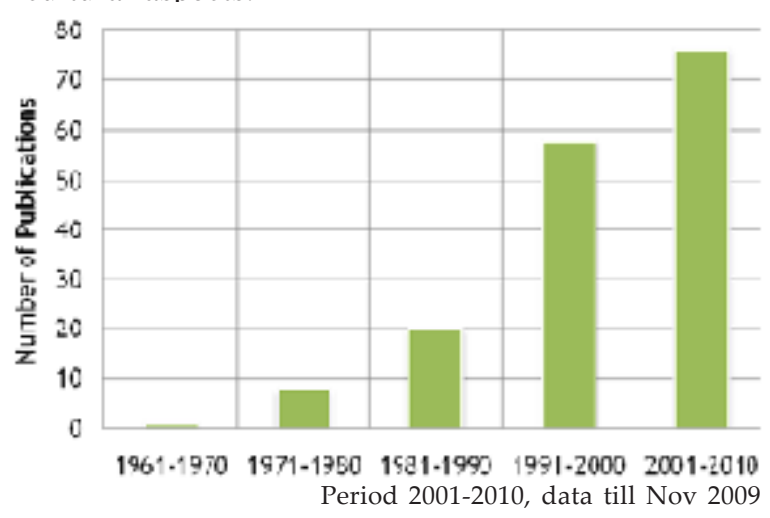

Fig. 2. Studies on lakes in Nepal 1961-2010

\section{Physiographic coverage}

Nepal boasts lakes of varied ecological conditions from subtropical lowland Tarai to high altitude alpine providing opportunities for wide array of studies. By physiographic zones, majority of Nepal's lakes and ponds are located in the high altitudes (51\%) and lowland (42\%), but much of the studies conducted so far were in the middle mountains, where 82 studies were carried out covering $50.3 \%$ of the total studies on lakes in Nepal (Fig. 3). Among the studies carried

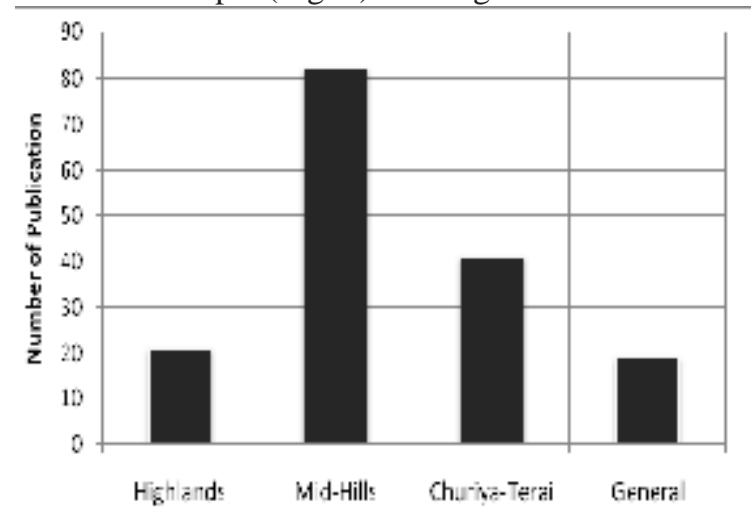

Fig. 3. Studies on lakes by physiographic zones in Nepal

out in the middle mountains, most of them were in Pokhara and Kathmandu valley. There were 41 studies conducted in Churiya-Terai region. From the remote high mountains, 21 publications were listed, half of which were based in Mount Everest region. Thus, there exists a stark discrepancy in the lakes studies in Nepal, which could be because of geographic remoteness and resource constraints. Of the total studies, majority (76\%) was conducted by Nepali researchers, $15 \%$ by foreigners and the rest jointly by Nepali and foreign scientists (Fig. 4).

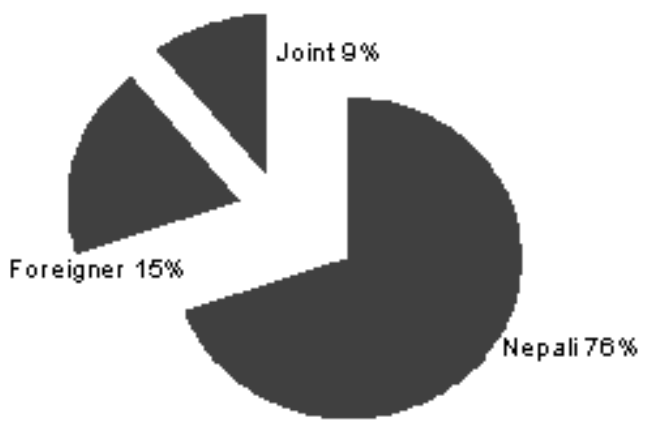

Fig. 4. Proportion of researchers on lake studies in Nepal

\section{Study scope}

The research studies carried out in the lakes and ponds of Nepal have covered various aspects of limnology (Ferro 1978, Okino \& Satoh 1986, Aizaki et al. 1987, Nakanishi et al. 1988, Jones et al. 1989, McEachern 1994, Tartari et al. 1998, Rai 2000, Lacoul \& Freedman 2005), plankton, macrophytes, macroinvertebrates (Manca et al. 1998, Bhatt et al. 1999, Dhakal 2007, Lacoul \& Freedman 2006), environmental change (Lami et al. 1998, Sharma et al 2009), diatoms (Hickel 1973a, b; Lohman et al. 1988, Jüttner et al. 1996, Rothfritz et al. 1997, Cantonati et al. 2001, Jüttner et al. 2003, 2004, Dahal \& Jüttner 2004, Simkhada 2007). Studies on the composition of vegetation surrounding the lakes have been carried out by Baral (1992), Bhattarai (1997), Acharya (1997), Rai (1998), Joshi et al. (2001), Siwakoti (2006) in order to understand the habitat type. Some studies have included both the vegetation and water quality (Adhikari 2009, Neupane 2009, Khadka 2009) while others focused on the relationship between floral composition and water quality (Acharya 1993, Shrestha 2002). Studies on seasonal change in physical and chemical parameters of lake waters have been useful in categorizing the lakes and their status (Lohman et al. 1988, Bhattarai 2007, Gautam \& Bhattarai 2008, Shrestha 2008).

As the lakes have been religious and pilgrimage sites for many communities in Nepal, research study scope has extended to their socio-cultural values and conservation aspects. IUCN (1998) listed over 20 lakes and ponds that are considered very holy by various religious groups. The cultural importance of the lakes have been studied and reported by Baral (1992), and Bhandari (2005). Recent studies on lakes have included listing the important dates of cultural/religious events (Adhikari 2009, Aryal 2009, Neupane 2009, Khadka 2009). On the conservation management and local 
knowledge, the works by Shrestha (2004), Gurung et al. (2005), Wagle et al. (2007) are worth mentioning here.

\section{Lakes in high mountains}

Aizaki (1985) studied trophic status and water quality of Lake Tilicho in Central Nepal Himalaya. The lake is one of the largest glacier-fed lakes with slightly turbid water color and strong chemical stratification. This study revealed a low concentration of total phosphorus (1-6 mg/l) and total nitrogen ( 0.16 to 0.25 $\mathrm{mg} / \mathrm{l})$ in water. The chemistry of 31 lakes at altitudes between 4,530m and 5,480m asl in the Khumbhu and Imja Khola valleys was considered, around a third of which was reported to have $\mathrm{Na}+$ and $\mathrm{Cl}-$ of marine origin transported by the summer monsoon (Tartari et al. 1997). Three groups of lakes with different levels of ion concentrations and silica were highlighted using cluster analysis. Palaeo-limnological analyses of four Himalayan lakes (Piramide Superiore, Piramide Inferiore, Lake 40 and Lake 70) were carried out in the Everest region. Despite being characterized by very slightly polluted chemical conditions, the sedimentary record of phytoplankton and benthic algae in lake Piramide Inferiore and Lake N. 40, showed that there have been periods of high productivity.

Rara, which is the biggest natural lake of the country, lies at an altitude of 2,990m asl in far western Nepal, and it has only one outlet that joins the river Karnali. Thermocline in this lake was visible below 14 to $50 \mathrm{~m}$ and temperature was recorded as 7.5 to $7.6^{\circ} \mathrm{C}$ (Ferro 1978, 1979). Similarly, the morphology, physics, chemistry and biology of the lake were studied, and high level of $\mathrm{pH}$, conductivity and total hardness was reported. The lake was classified as oligotrophic in limnological terms (Okino \& Satoh 1986). studied on The impacts of global climatic change on biodiversity of high altitude lake Gokyo in Everest region was studied recently (Sharma et al. 2009).

\section{Lakes and ponds in Kathmandu valley}

It is said that Kathmandu valley was a big lake, and a legendary Manjushri drained it at Chovar gorge for the settlement. Natural lake as remnant of this is represented by Taudah near the gorge. Various biological components including phytoplankton and physicochemical parameters of water samples of Taudah pond in Kathmandu valley have been studied by Hickel (1973), Bajracharya (1982), Acharya (1997), Bhatta (1997), and Acharya (2003). Amore detailed investigation on chemical aspects of Taudaha and Nagdaha - the largest ponds in the valley was performed by Lohman et al. (1988), Jones et al. (1989). Similarly, ponds in Kirtipur and Bhaktapur have been studied both chemically and microbiologically (Joshi 1979, Parajuli 1997)), and these studies reveal high levels of chloride and phosphate as well as coliform bacteria.

\section{Lakes in Pokhara valley}

Pokhara valley contains several lakes, the most popular are: Phewa, Rupa, Begnas and Khaste, which finally drain their water into the Saptagandaki river system. These lakes are well studied compared to other regions. Temperature, transparency, electrical conductivity, $\mathrm{pH}$ and alkalinity of the lakes were investigated followed by species composition, vertical distribution and seasonal variations of phytoplankton (Hickel 1973b). Three major lakes (Phewa Tal, Begnas Tal, and Rupa Tal) were investigated in two seasons to examine the influence of monsoon on their limnological conditions (Lohman et al. 1988). Calcium concentration in Phewa Tal accounted for $66.3 \%$ of the cation and $43 \%$ in Begnas Tal and Rupa Tal; anions were predominantly bicarbonate in all three lakes. The most complete limnological investigation was carried out in Nepal in 1989, in which 50 lakes were surveyed, including the lakes from Pokhara Valley (Jones et al. 1989). Rai (2000) studied and analyzed limnological characteristics in three lakes of Pokhara (Phewa, Begnas and Rupa) from 1993 to 1997 . The water temperature ranged from $12{ }^{\circ} \mathrm{C}$ to $29^{\circ} \mathrm{C}$ in all lakes.

\section{Lakes in Churiya-Tarai region}

The wetland list prepared by IUCN (1992) mainly included lakes and ponds from the lowland Terai of Nepal. Devital, Lamital and Tamortal were investigated in Chitwan National Park and classified as oligotrophic. Limnological work on the lakes of far western region of Nepal is limited (Metcalf \& Eddy 2000). Bhuju (2004) recorded some lakes in the dry lands of Churiya hills and highlighted their importance. Recently, Adhikari (2009), Neupane (2009) and Khadka (2009) studied the water quality and surrounding vegetation of dryland lakes of Churiya hills in far western Nepal, viz. Jhilmila, Betkot and Mudka Tal. Studies were carried out in Beeshhazari Tal in Chitwan (Jayana 1997, Burlakoti \& Karmacharya 2004), Ghodaghodi in Kailali (Baral 1992, Acharya 1997). The compositions of benthic macroinvertebrates of two ponds in Mahottari district were studied by Mahato \& Yadav (1984), and 31 taxa were recorded, and the pond was classified as eutrophic. 
Table 1. Common flora and fauna in wetlands of different physiographic zones of Nepal

Physiographic zones
High Mountain
More than 16 glacial
lakes, 8 fresh water
tectonic lakes are
distributed in this region.
Popular lakes of this
region are Panch Pokhari,
Dig Tsho, Torju, Gosain
Kund, Bhairav Kund,
Tilicho, Phoksundo and
Rara. Lirnological
condition is oligtrophic
type as human
distrbution and
disturbances are less.
Rara lake location at
2990 m is the largest
(1036 ha) and deepest
(167 m) lake in Nepal
followed by Phoksundo
lake.

\section{Middle Mountain}

Generally include tectoric fresh water lakes and rain fed river flood plain. Ponds, reservoirs and rice paddies crusted in between rugged hills and mountains of Mahabharat and Churia range. Phewa, Begnas, Rupa, Maidi, Dipong and Titi in Pokhara in west Nepal. Hydroelec tric reservoir such as Trishuli, Marshayangdi and Kulekhari, and may Daha's, pools and ponds occur in this region. On the basis of the ir produc tivity the wetlands here are mostly mesotrophic or eutrophic.

Fora
All the glacial lakes are devoid of
macro aquatic vege tation. The
macro aquatic vege tation. The dominant aquatic flora are: reed (Phragmatis sp), rushes (Juncus sp.), sedges (Frimbristy lis sp.) in the littoral zone, and Myriophylum sp. in shallow water. Open meadows harbor species like Polygonum miletii, Opygraphis polypetala and Ranunculus sp.

As the water is in mesotrophic and eutrophic state, ve ge tations are comparatively richer than high mountairs. The most abundant aquatic plants of this region comprise: Alternenthera sessilis, Ceratophylium demursum, Cpperus defformis, C iria, Eichhomia crassipes, Eriocaulon nepalensis, Hydrilla wricillata,

Lecanthus peduncularis, Mariscus sumatrensis, Mo nochorea vaginalis, Myniophllum sp., Majas sp., Naxurtium officinale, Nymphaea sp. Mymphoides indicum, Persicaria sp, Polygonum hydropiper, Potamogeton crispus, $P$. pectinatus, Ranunculus scleratus, Rumex sp., Scirpus articulates, Spirodela polyrhiza, Trapa bispinosa, Urticularia sp., Vallisneria sp., Wolfia sp., etc. Species diversity is the highest in the fresh water lintic bodies followed by slow moving shallow lotic bodies away from dense hurnan settle met.

$\begin{array}{ll}\text { Fauna } & \text { Reference } \\ \text { No fauna hwe been reported so far from } & \text { Ferro } 1979 \\ \text { the glacial lakes. In Fresh water tectonic } & \text { Scott } 1989 \\ \text { lakes harbor some fauna. } & \text { Loffler } 1969 \\ \text { Mammals: Smooth otter (Lutra } & \text { Shrestha, } \\ \text { perpicillata), Volve (Pitymys sikimen sis), } & \text { T.K. } 1994 \\ \text { alpine vole (Apodemus flavicollis } & \text { Shrestha, P. } \\ \text { gurkha), Tibe tan water shrew (Nectigale } & 1994 \\ \text { elegans). } & \text { Mbog et al. } \\ \text { Birds: Bar headed goose (Anas indicus), } & 2008\end{array}$
she lduck (Tadorna ferruginea), cormmon teal (Anas crecca), mallard (Anas platy rhnchos), crested poachard (Aythya fuligula).

Amphbians: Himalayan toad (Bufo himalayaensis).

Fishes: Snow trouts (Schizothorax nepalensis, $S$ macrothalames, $S$. rarensis), sucker head (Garra sp.) and stone loach (Neomacheillus sp.)

Others: Stone flies (nemourids, capriids, taeniopte rygiids), Mayflies (he ptage niids, baetids), Caddisflies (rhyacophilids), Diptera (simuliids, tabanids, chironornids)

Mammak: Smooth otter (Lutra perspicillata), small clawed otter (Aonyx cinerea), fishing cat (Felis viverno).

Birds: Pied king fisher (Ceryle nudis), $\operatorname{coot}$ (Fulica atra), purple moorhen (Porphyrio porphyrio), bronze winged Junc ana (Metopiduis indicus), teal (Anas creeca), Pintail (Anas acuta), Cattle erget

(Balbulcus ibis) common snipe (Gallinago gallinago), Mellard (Anas platyrhynchos) Fond he ron (Aroleola greyii).

Amphibians: Frog (Rana esculenta, $R$ tigrina, $R$ hexadactyla, $R$ limmochoris), Himalayan ne wt (Tylototriton verncosis)

Fishes: Mountain trout (Schizothorax richardsonii), copper mahseer (Acrossocheilus hexagonalepis) and golden mahseer Toputitora Others: Stone flies (perlids, perlodids), Mayflies (caenids-Caenis sp., heptageniids-Epeorus rhithralis, Rhithrogena nepalensis; baetids-Baetis sp, Baetiella sp.), Caddisflies (hydropsychids, rhyacophilids, leptophlebiids- Euthraulus sp.), Mblusca (unionids, plnorbids, physids-Phy sa sp), Diptera (Simuliids, pescho myiids, tabanids, chironomids), Crabs (potamo nids).
Manandhar

1978

East

consultant

1990

GEOCE 1991

Yadav et al. 1983

Joshi 1973

Rajbhandari

1982

Moog et al. 2008 


\begin{tabular}{|c|c|c|c|}
\hline $\begin{array}{l}\text { Low lands and Terai } \\
\text { Major rivers such as } \\
\text { Mahakali, Kamali, Rapti, } \\
\text { Gardaki and Koshi have } \\
\text { extensive flood plains } \\
\text { and marshlands. Ox-box } \\
\text { lakes have dominance } \\
\text { over this region. On the } \\
\text { basis of their } \\
\text { productivity, the } \\
\text { wetlands here are mostly } \\
\text { mesotrophic and } \\
\text { e utrophic. Terai flood } \\
\text { plains depend on } \\
\text { seasonal flooding from } \\
\text { rvers for the high } \\
\text { diversity of their endernic } \\
\text { life-forms. }\end{array}$ & $\begin{array}{l}\text { The most abundant aquatic flora } \\
\text { of this region include: } \\
\text { Alternanthera sessilis, } \\
\text { Arundinaria sp., Arundo donax, } \\
\text { Chenopodium ambrosioides, } \\
\text { Cynodon dactylon, Cyperus iria, } \\
\text { C mersuri, Eichhornia crassipes, } \\
\text { Eulaliopsis fnata, Euryale ferox, } \\
\text { Meteron contratus, Imperata } \\
\text { cylindrical, Ipomia aquatic, } \\
\text { Monochorea vaginalis, Perscaria } \\
\text { sp., Pistia sratitoles, Phragmatis } \\
\text { karak, Polygonum ple bejum, } \\
\text { Ranunculus sceleratus, } \\
\text { Sacchanum spontaneum, } \\
\text { Sagittaria trifolia, Scrpus sp., } \\
\text { Setaria pallidefusca, Themeda } \\
\text { villosa, Trapa biopinosa, Typha } \\
\text { angustifoia, Vetiveria lawssonii. }\end{array}$ & 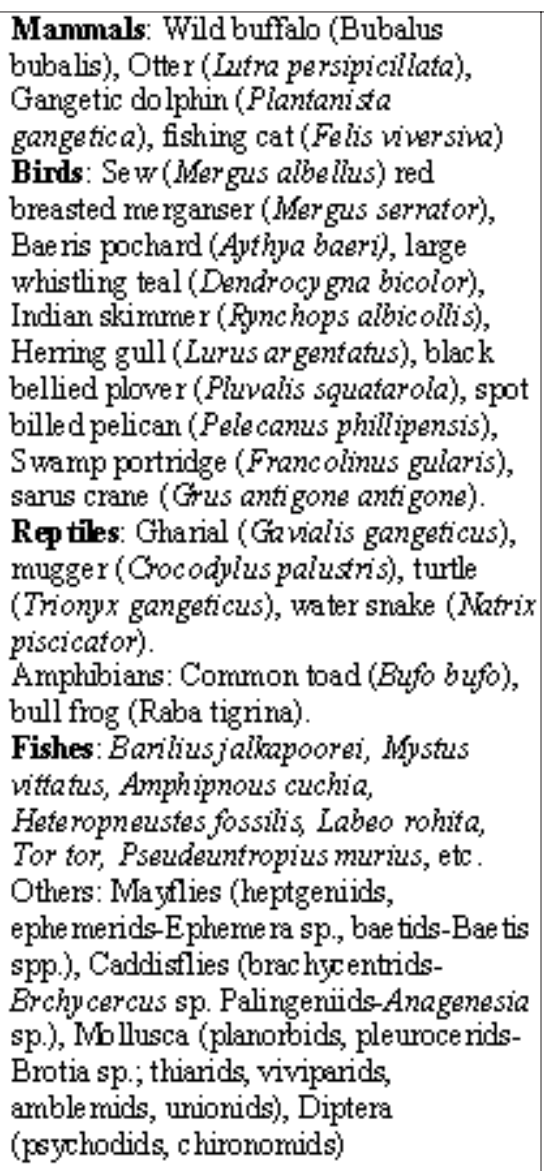 & $\begin{array}{l}\text { Bhatt \& } \\
\text { Shrestha } 1973 \\
\text { New Era } \\
1987 \\
\text { Dinerstein } \\
1979 \text { ab } \\
\text { Scott } 1989 \\
\text { Inskipp \& } \\
\text { Inskipp } 1985 \\
\text { Bauer et al. } \\
1994 \\
\text { Moog et al. } \\
2008\end{array}$ \\
\hline
\end{tabular}

Modified from Jha and Lacoul 1998

\section{Lakes and biodiversity}

It is estimated that nearly one fourth of Nepal's biodiversity occurs in wetland/lake dependent (Bhandari 1992).The occurrence of lakes and ponds in diverse ecological zones have made it rich in flora, thus, supporting significant number of aquatic and/or fresh water dependent fauna (Jha \& Lacoul 1998). Table 1 consists common flora and fauna found in wetlands of three different physiographic zones of Nepal, viz. High Mountains, Middle Mountains and Lowland Terai. The High Mountains include mainly glacial lakes and tectonic lakes such as Rara, Phoksundo, Tilicho and Gosaikunda. They are oligotrophic and contains less diversity of flora with reed and sedges. The glacial lakes are almost free from fauna; however, the tectonic lakes contain some mammals (e.g., smooth otter, vole), birds (e.g., bar headed goose, shelduck, etc.), amphibians (e.g., Himalayan toad), and fishes (e.g., snow trout). The lakes of Middle Mountains are generally of tectonic origin and rain-fed. The water is mesotrophic or eutrophic, and is comparatively rich in flora and fauna. The lowland Tarai contains rivers with flood plains and ox-bow lakes, and they are mesotrophic or eutrophic with rich biodiversity.

\section{Threats and Issues}

Anthropogenic impacts on lakes are spreading in most parts of the world and becoming more intense in quantity and quality due to increased human population and their activities. The high rate of deforestation and use of pesticides and fertilizers have spurred the spread of invasive species (Ayres et al. 1996, French 2000). Direct human influence is mostly absent in remote aquatic systems in the high Himalaya; however, anthropogenic activities are intense in midland and lowland and lead to eutrophication, pollution and degradation of water bodies particularly in urban and agricultural areas (Pandit 1999, Rai 2000, Thapa \& Weber 1995). Diversion of lake water for use 
DR Bhuju et al./Scientific Discourse of Lakes in Nepal

in irrigation and industry, invasions of plant and introduction of exotic animal species, and contamination of toxics and nutrients from industry, farms, sewage, and urban runoff are common today that significantly threatens lake ecosystems (Abramovitz 1996, Ayres et al. 1996, Jorgensen \& Matsui 1997, Groombridge \& Jenkins 1998, Postel 1999, Duda \& El-Ashry 2000, Hall \& Mills 2000, Khan \& Siddique 2000, Lemly et al. 2000, Revenga et al. 2000).

In Nepal, there are multiple threats to standing freshwater ecosystems. These include phenomena which occur naturally due to highly dynamic processes linked to geographical characters such as geomorphology and climatic conditions, in particular erosion, transportation, sedimentation and other hydrological changes. During the last decades many lakes and ponds in urban areas have been either degraded or disappeared due to expansion of settlements, heavy abstraction of groundwater and intensification of agriculture (Jha 1992). Many of the ponds are facing extinction, especially when they are in proximity to human settlements. Large numbers of ponds are either in the process of being overgrown by invasive plants due to management apathy.

Despite their great historical and cultural significance, potential economic value and importance for conserving aquatic biodiversity, ponds, lakes and other freshwater ecosystems in the Kathmandu valley are subjected to pollution and habitat degradation (Jüttner et al. 2003). Simkhada (2007) reported that many of the investigated ponds and lakes in covering high Himal, Midhills and lowland Tarai, are used inappropriately such as washing, dumping of litter and receive pollutants from drainage pipes, surface runoff and air pollution. Lakes in the high altitudes, such as Gosainkund are at risk of acidification, eutrophication, etc. due to their geology composed of base-poor bedrock.

Climate related changes such as altered levels of UV radiation and temperature, and the rising atmospheric pollution over the Indian sub-continent is also seen as threat which may have significant effects on sensitive ecosystems. Findings suggest that acid depositions are the most likely source of pollution at present affecting high altitude lakes in the Gosainkund area during spring (Simkhada 2007). Their value as religious site has also caused human originated alteration in nutrient concentrations and biological assemblages of the lake. The need for further investigations to assess consequences of long distance transport of atmospheric pollutants and other anthropogenic impacts for these sensitive ecosystems has been stressed by some authors (Lami et al. 1998, Tartari et al. 1998). Melting of glaciers in high altitude lakes also pose serious threat (Bajracharya et al. 2007).

Altogether 278 lakes lie inside the protected areas, i.e., less than four per cent of the total lakes in Nepal. While many of these studies focus on water quality (physical, chemical and microbial) of lakes, studies on their structural properties such as morphometry, bathymetry, hydrology, limnology and ecology are very limited. Survey and mapping of lakes to prepare their national inventory and resource contents, land-use history, land ownership, lake-ontogeny, and terrestrial biodiversity influencing the lake ecosystem are almost nonexistence. This, on the positive note, indicates that there is high opportunity of unveiling new findings from the scientific studies of lakes and ponds in Nepal.

\section{References}

Abramovitz, J. 1996. Imperiled waters, impoverished future: the decline of freshwater ecosystems. Worldwatch Paper 128. Worldwatch Institute, Washington DC.

Acharya, N. 1997. Biological and physico-chemical investigation of the ponds of Katmandu valley. M.Sc. thesis. Central Department of Botany, Tribhuvan University, Katmandu, Nepal.

Acharya, N.R. 2003. Floristic study of wetlands in Kathamdu district: A case study of Taudaha lake. M.Sc. thesis. Central Department of Botany, Tribhuvan University, Kathmandu.

Acharya, P. 1997. Wetlands vegetation and its utilization in Ghodaghodi and Nakhrodi Tal, Kailali, Nepal. M.Sc. thesis. Central Department of Botany, Tribhuvan University, Kathmandu.

Adhikari, R. 2009. Status of water quality, surrounding terrestrial vegetation and socio-cultural values of Mudka Tal, far-western Nepal. M.Sc. thesis. Central Department of Environment Science, Tribhuvan University, Kathmandu.

Aizaki, M. 1985. Trophic status and water quality of high altitude lakes in Mt Annapurna region. Sec. Microb. Exped. Jpn: 15-26.

Aizaki M., A.Terashima, H. Nakahara, T. Nishio and Y. Ishida. 1987. Trophic status of Tilitso, a high altitude Himalayan lake. Hydrobiologia 153: 217-224.

Aryal, N. 2009. Biodiversity assessment of wetland: a study on the Mardhar wetland Rautahat. M.Sc. Thesis. Central 
Department of Environmental Science. Tribhuvan University, Kathmandu.

Ayres, W., A. Busia, A. Dinar, R. Hirji, S. Lintner, A. McCalla and R. Robelus. 1996. Integrated lake and reservoir management: World Bank approach and experience. World Bank Technical Paper No. 358, Washington DC.

Bajracharya, S.R., P.K. Mool, and B.S. Shrestha. 2007. Impact of climate change on Himalayan glaciers and glacier lakes. International Centre for Integrated Mountain Development - United Nations Environment Programme Regional Office Asia and the Pacific, Kathmandu.

Bajracharya, T.L. 1982. Aquatic vegetation of some ponds and a lake in Kathmandu valley. M.Sc. thesis. Central Department of Botany, Tribhuvan University, Kathmandu.

Baral, H.S. 1992. Ghodaghodi lake system: A national treasure. Report, Asia Wetland Bureau, DOF, DNPWC, ICBP and IUCN, Nepal Bird Watching Group.

Bauer, J.J., T. Maskey and G. Raut.1994. River systems, hydro development and the species crisis in Terai. Safeguarding Wetlands in Nepal (Eds. B. Bhandari, T.B. Shrestha and J. McEachern) IUCN Nepal. Pp. 137-145.

Bhandari, B. 1992.The current status of wetlands in Nepal. Country report presented at the Asian Wetland Symposium (Oct 14-20), Otsu, Japan.

Bhandari, B. 2005. Lakes, culture and traditional belief: Examples from Nepal. In: Proceedings of the $11^{\text {th }}$ World Lakes Conference (Oct 31-Nov 4, 2005) Nairobi (Eds. E.O. Odada, D.O. Olago, W. Ochola, M. Ntiba, S. Wandiga, N. Gichuki \& H. Oyieke) Nairobi, Kenya.

Bhatta, D.D. and T.K.Shrestha. 1973. The Environment of Shuklaphanta. Curruculum Development Centre, Tribhuvan University, Kathmandu.

Bhatta, L.R. 1997. Physico-chemical characteristics and phytoplanktons of Taudaha lake. M.Sc. thesis. Central Department of Botany, Tribhuvan University, Kathmandu.

Bhatt, L.R., P. Lacoul, H.D. Lekhak and P.K. Jha. 1999. Physico-chemical characteristics and phytoplanktons of Taudaha lake, Kathmandu. Pollution Research 18: 353-358.

Bhattarai, B. 2007. Understanding water quality of Beeshazar tal complex in Nepal. M.Sc. thesis. Central Department of Environmental Science, Tribhuvan University, Kathmandu.

Bhattarai, D.B. 1997. Analysis of vegetation and their utilization in the wetlands of the Royal Bardia National Park (Karnali-Chisapani sector). M.Sc. thesis. Central Department of Botany, Tribhuvan University, Kathmandu.

Bhuju, D.R. 2004. Lakes in drylands. Hakahaki 7(3): 2427.
Bhuju, D.R. and N.P. Gaire. 2010. Bibliography of lake study in Nepal. Nepal Academy of Science and Technology, Kathmandu. pp 28.

Bhuju, U.R., M. Khadka, P.N. Neupane, R. Adhikari. 2009. Lakes of Nepal: 5358 - Map Based Inventory. National Lakes Conservation and Development Committee, Kathmandu.

Burlakoti, C. and S.B. Karmacharya. 2004. Quantitative analysis of macrophytes of Beeshazar Tal, Chitwan, Nepal. Him. J. Sci. 2(3): 37-41.

Cantonati, M., G. Corradini, I. Jüttner and E.J. Cox. 2001. Diatom assemblages in high mountain streams of the Alps and the Himalaya. Nova Hedwigia Beiheft 123: 37-61.

Dahal, B.M. and I. Jüttner. 2004. Monitoring water quality in springs of the Nepalese middle hills using diatoms. Report to the British Ecological Society SEPG No.2235-2003.

Dhakal, S. 2007. A study on composition of macrophytes in relation to physico-chemical parameters of Beeshazar lake a Ramsar site of Chitawan, Nepal. M.Sc. thesis. Central Department of Environmental Science, Tribhuvan University, Kathmandu.

Dinerstein, E. 1979a. An ecological survey of the Royal Karnali Bardia Wildlife Reserve, Nepal. Part I. Vegetation, modifying factors and successional relationships. Biological Conservation 16: 265-300.

Dinerstein, E. 1979b. An ecological survey of the Royal Karnali Bardia Wildlife Reserve, Nepal. Part II. Habitat/ animal interactions. Biological Conservation 15:127-150.

Duda, A. and M. El-Ashry. 2000. Addressing the global water and environment crises through integrated approaches to the management of land, water and ecological resources. Water International 25(1):115-126.

East Consultant.1990. Environmental Impact Study of Drinking Water supply in Kathmandu and Lalitpur from outside the valley, Kathmandu. East consultant, Kathmandu.

Ferro, W. 1978. Limnology of the Pokhara valley lakes (Himalayan region, Nepal) and its Implication for fishery and fish culture. Report Integrated Fishery and Fish Culture Development Project, FAO, Rome.

Ferro, W. 1979. Some limnological and biological data from Rara, a deep Himalayan lake in Nepal. J. Nepal Res. Center 2/3: 241-261.

Fisheries Development Division. 1992. National fisheries development plan 1992/93. FDD, Department of Agriculture Development, Kathmandu.

Franch, R.L. and R.H. Peters. 1995. Predictive model of the effects on lake metabolism of decreased airborne litterfall through riparian deforestation. Conservation Biology 9(6):1578-1586.

Gautam, B. and B. Bhattarai. 2008. Seasonal changes in water quality parameters and sediment nutrients in 
Jagdishpur Reservoir, a Ramsar site in Nepal. Nepal J. Sci. Tech. 9: 149-156.

GEOCE. 1991. Environmental Impact Study to Assess Effect on Irrigation and Ecology along Jhomsuk Khola. Final report submitted to BPC Hydropower Consult, Kathmandu.

Groombridge, B. and M. Jenkins. 1998. Freshwater biodiversity: a preliminary global assessment. UNEP and World Conservation Monitoring Centre. World Conservation Press.

Gurung, T.B., S.K. Wagle, J.D. Bista, R.P. Dhakal, P.L. Joshi, R. Batajoo, P. Adhikari and A.K. Rai. 2005. Participatory fisheries management for livelihood improvement of fishers in Phewa Lake, Pokhara, Nepal. Himalayan J. Sciences 3(5): 47-52.

Hall, S. and E. Mills. 2000. Exotic species in large lakes of the world. Aquatic Ecosystem Health and Management 3: $105-135$

Hickel, B. 1973a. Limnological investigations in lakes of the Pokhara valley, Nepal. International Review of Hydrobiology 58: 659-672.

Hickel, B. 1973b. Phytoplankton in two ponds in Kathmandu Valley, Nepal. International Review of Hydrobiology 58 : 835-842.

Inskipp, C. and T. Inskipp. 1985. A Guide to the Birds of Nepal. Croom Helm, Beckenham, UK, 392pp.

IUCN. 1992. An inventory of Nepal's Terai wetlands. IUCN Nepal, Kathmandu.

IUCN. 1998. The Ghodaghodi Tal conservation area: A community centered management plan. IUCN Nepal, Kathmandu.

Jayana, B. 1997. Abiotic and biotic environment of Bishazaar Tal in Tikauli jungle, Chitwan. M.Sc. Central Department of Zoology, Tribhuvan University, Kathmandu.

Jha, P.K. 1992. Environment and Man in Nepal. Craftsman Press, Bangkok, 113pp.

Jha, P.K. and P. Lacoul. 1998. Wetlands in Nepal: Status, significance and management. In: Ecology of Wetlands and Associated Systems (Eds. S.K. Majumdar, E.W. Miller \& F.J. Brenner). The Pennsylvania Academy of Science, USA, pp 648-669.

Jones, J.R., M.F. Nowlton, and D.B. Swar, 1989. Limnological reconnaissance of water bodies in central and southern Nepal. Hydrobiologia 184: 171-189.

Jorgensen, S. and S. Matsui (Eds.). 1997. Guidelines of lake management: The world's lakes in crisis 8. International Lake Environment Committee and the United Nations Environment Programme. Shiga, Japan.

Joshi, S.D., R.P. Chaudhary and P.B. Shrestha. 2001. Wetlands of Kathmandu valley: inventory and management strategy. Report, MOPE/GON, Kathmandu.

Joshi, C.L.1979. Comparative studies on biological and physico-chemical features of ponds at Kirtipur. M.Sc. thesis. Central Department of Environmental Science, Tribhuvan University, Kathmandu.

Joshi, S.D. 1973. Dominant aquatic angiosperms in Taudah. J. Sc. Nepal 5(1):14-17.

Joshi, S.D., R.P. Chaudhary and P.B. Shrestha. 2001. Wetlands of Kathmandu valley: Inventory and management strategy. Report MOPE/GON, Kathmandu.

Jüttner, I., H. Rothfritz and S.J. Ormerod. 1996. Diatoms as indicators of river quality in the Nepalese middle hills with consideration of the effects of habitat-specific sampling. Freshwater Biology 36: 475-486.

Jüttner, I., S. Sharma, B.M. Dahal, S.J. Ormerod and E.J. Cox. 2003. Diatoms as indicators of stream quality in the Kathmandu valley and middle hills of Nepal and India. Freshwater Biology 48: 2065-2084.

Jüttner, I., E. Reichardt E. and E.J. Cox. 2004. Taxonomy and ecology of some new Gomphonema species common in Himalayan streams. Diatom Research 19: 235- 264.

Khadka, M. 2009. Water quality, vegetation composition and socio-culture values of dryland lake Jhilmila Tal in far-western Nepal. M.Sc. thesis. Central Department of Environmental Science, Tribhuvan University, Kathmandu.

Khan, H. and Q. Siddique. 2000. Urban water management problems in developing countries with particular reference to Bangladesh. Water Resources Development 16(1).

Lacoul, P. and B. Freedman. 2005. Physical and chemical limnology of 34 lentic waterbodies along a tropical-toalpine altitudinal gradient in Nepal. International Rev. Hydrobiology 90: 254-276.

Lacoul, P. and B. Freedman. 2006. Recent observation of a proliferation of Ranunculus trichophyllus Chaix. in highaltitude lakes of the Mount Everest Region. Arctic, Antarctic, and Alpine Research 38(3): 394-398.

Lami, A., P. Guilizzoni, A. Marchetto, R. Bettinetti and D.J. Smith. 1998. Paleolimnological evidence of environmental changes in some high altitude Himalayan lakes (Nepal). In: Limnology of high Altitude Lakes in the Mt Everest Region (Himalayas, Nepal), (Eds. A. Lami \& G. Giussani), Memorie dell'Istituto Italiano di Idrobiologia 57: 107-130.

Lemly, D., R. Kingsford and J. Thompson. 2000. Irrigated agriculture and wildlife conservation: conflict on a global scale. Environmental Management 25(5): 485-512.

Löffler, H. 1969. High altitude lakes in Mt Everest region. Verhandlungen Internationale Vereinigung Limnologie 17: 373-385.

Lohman, K., J.R. Jones, M.F. Knowlton, D.B. Swar, M.A. Pamperl and B.J. Brazos. 1988. III. Lakes. 3. Asia: Pre and postmonsoon limnological characteristics of lakes in the Pokhara and Kathmandu valleys, Nepal. Verhandlungen Internationale Vereinigung Limnologie 23: 558-565. 
Mahato, M. and U.K.R. Yadav. 1984. The composition of benthic macroinvertebrates of two ponds of Mahottari district, Nepal. J. Nat. Hist. Mus. 8: 7988.

Manandhar, M. 1978. A study of weeds on the river bank of Kathmandu valley. Bull. Bombay Survey, India, 20:36-47.

Manca, M., D. Ruggiu, P. Panzani, A. Asioli ,G. Mura and A.M. Nocentini. 1998. Report on a collection of aquatic organisms from high mountain lakes in the Khumbu valley (Nepalese Himalayas). In: Limnology of high altitude lakes in the Mt Everest region (Himalayas, Nepal), (Eds . A. Lami \& G. Giussani), Memorie dell'Istituto Italiano di Idrobiologia 57: 77-98.

McEachern, P. 1994. Limnology and the national wetlands survey. In: Safe Guarding Wetlands in Nepal. (Eds. B. Bhandari, T.B. Shrestha \& J. McEachern.), IUCN Nepal, Kathmandu, pp. 88103.

Metcalf and Eddy. 2000. Paper presented at a Seminar on Groundwater and Waste Water, Melamchi Water Supply Development Board,14 February 2000, Kathmandu, Nepal.

Moog, O., D. Hering, S. Sharma, , I. Stubauer,, and T. Korte (eds.) ASSESS-HKH: Proceedings of the Scientific Conference "Rivers in the Hindu-KushHimalaya- Ecology and Environmental Assessment, ISBN 978-3-00-024806-1.

Nakanishi, M., M.M.Watanabe, A.Terashima, Y. Sako,T. Kondo, K. Shrestha, H. Bhandary and Y. Ishida. 1988. Studies on some limnological variables of subtropical lakes of the Pokhara valley, Nepal. Japanese Journal of Limnology 19: 71-86.

Neupane, P.K. 2009. Assessment of wetland for conservation and management in Churiya hill: A study of Bedkot Tal, Kanchanpur, far-western Nepal. M.Sc. thesis. Central Department of Environment Science, Tribhuvan University, Kathmandu.

New Era. 1987. The Karnali (Chisapani) multipurpose project. Envirionment and Socio-economic Situation Report. Vol. 1. Main Report, New Era, Kathmandu.

Okino,T. and Y. Satoh. 1986. Morphology, physics, chemistry and biology of Lake Rara in West Nepal. Hydrobiologia 140: 125-133.

Pandit, A.K. 1999. Freshwater ecosystems of the Himalaya. Panthenon Publishing, New York.

Parajuli, S.P. 1997. Seasonal fluctuation in phytoplanktons and physic-chemical parameters of water in Kamal Pokhari, Bhaktapur. M.Sc. thesis. Central Department of Botany, Tribhuvan University, Kathmandu.

Postel, S. 1999. Pillar of sand. Worldwatch Institute. Washington, DC.
Rai, A.K. 2000. Limnological characteristics of subtropical lakes Phewa, Begnas and Rupa in Pokhara valley, Nepal. Limnology 1: 33-46.

Rai, A.K. 1998: Trophic status of Phewa, Begnas and Rupa in Pokhara valley, Nepal. Journal of Lake Science 10 : 179-200.

Rajbhandari, S. 1982. Floristic study and distribution of aquatic angiosperms in Kathmandu Valley. M.Sc. thesis. Central Department of Botany, Tribhuvan University, Kathmandu.

Revenga, C., S. Murray, J. Abramovitz and A. Hammond. 1998. Watersheds of the world: ecological value and vulnerability.

Rothfritz, H., I. Jüttner, A.M. Suren and S.J. Ormerod. 1997. Epiphytic and epilithic diatom communities along environmental gradients in the Nepalese Himalaya: implications for the assessment of biodiversity and water quality. Archiv für Hydrobiologie 138: 465-482.

Scott, D.A. (Ed.). 1989. A directory of Asian wetlands. IUCN, Gland and Cambridge, 181pp.

Sharma, C.M., S. Sharma, S. Gurung, R.M. Bajracharya and I. Jüttner. 2009. Study on morphometry and limnology of Gokyo wetland with climate change perspective. Report submitted to WWF Nepal Program, Kathmandu.

Sharma, S., R.M. Bajracharya, B.K. Sitaula and Juerg Merz. 2005. Water quality in the central Himalaya. Current Science 89(5): 774-786.

Shrestha, P. 1994. Wetland flora in Nepal. In: Safeguarding Wetlands in Nepal (Eds. B. Bhandari, T.B. Shrestha \& J. McEachern) IUCN Nepal. Pp. 53-65.

Shrestha, P. 2004. Conservation and management of Phewa Lake ecosystem, Nepal. In: Proceedings of the international conference on great Himalayas: climate, health, ecology, management and conservation. KU/ AEHMS/ HIRI, Kathmandu.

Shrestha, R.R. 1995. Limnological investigation of Gosainkund lake and impact of Janaipurnima festival. Environment and Public Health Organization, Kathmandu.

Shrestha, T.K. 1994. Wetland fauna in Nepal. Safeguarding Wetlands in Nepal (Eds. B. Bhandari, T.B. Shrestha and J. McEachern) IUCN Nepal. Pp. 41-52.

Shrestha, U.B. 2002. Analysis and management of wetland flora of Nagdah, Lalitpur, Nepal. M.Sc. thesis. Central Department of Botany, Tribhuvan University, Kathmandu.

Shrestha, S. 2008. A study on water quality parameters and benthic micro-invertibrates of Taudaha lake, Kathmandu. M.Sc. thesis. Central Department of Environmental Science, Tribhuvan University, Kathmandu.

Singh, S.K. 2002. Revitalization of ponds for sustainability of town. M. Sc. thesis. Institute of Engineering, Tribhuvan University, Kathmandu. 


\section{DR Bhuju et al./Scientific Discourse of Lakes in Nepal}

Simkhada, B. 2007. Diatoms as indicators of environmental change in lakes and ponds of the lowlands, middle mills and high Himalaya of Nepal. Ph.D. Thesis, University of Bielefeld.

Siwakoti, M. 2006. An overview of floral diversity in wetlands of Terai region of Nepal.

Thapa G.B. and K.E. Weber. 1995. Status and management of watersheds in the upper Pokhara valley, Nepal. Environmental Management 19: 497-513.

Tartari, G.A., G. Tartari and R. Mosello. 1997. Water chemistry of high altitude lakes in the Khumbu and Imja Kola Valleys (Nepalese Himalayas). Mem. Ist. Ital. Idrobiol 57: 51-76.
Tartari, G.A., G. Tartari and R. Mosello. 1998. Water chemistry of high altitude lakes in the Khumbu and Imja Kola valleys (Nepalese Himalayas). In: Limnology of high altitude lakes in the Mt Everest region (Himalayas, Nepal), (Eds. A. Lami \& G. Giussani), Memorie dell'Istituto Italiano di Idrobiologia 57: 51-76.

Wagle, S.K., T.B. Gurung, J.D. Bista and A.K. Rai. 2007. Cage fish culture and fisheries for food security and livelihoods in mid hill lakes of Pokhara valley, Nepal: Post community based management adoption. Aquaculture Asia 12( 3):14.

Yadav, U.K., G.P.S. Ghimire and A. Amatya. 1983. Biological investigation of Taudaha lake. J. Nat. Hist. Mus. 7(1):114. 
Nepal Journal of Science and Technology Vol. 13, No. 2 (2012) 147-158 